\title{
ANALISIS EFEKTIVITAS BIAYA PENGGUNAAN TERAPI INSULIN DAN INSULIN KOMBINASI PADA PASIEN DIABETES MELLITUS TIPE II RAWAT JALAN DI RSUP SANGLAH
}

\author{
ANALYSIS OF COST EFFECTIVENESS USE OF INSULIN THERAPY AND INSULIN \\ COMBINATION ON DIABETES MELLITUS TYPE II OUTPATIENTS IN RSUP SANGLAH
}

\author{
I MADE AGUS SUNADI PUTRA ${ }^{1}$, NI NYOMAN WAHYU UDAYANI ${ }^{1 \bullet}$, HERLEEYANA MERIYANI $^{1}$ \\ ${ }^{1}$ Akademi Farmasi Saraswati Denpasar, Jalan Kamboja No 11A Denpasar
}

\begin{abstract}
Abstrak: Diabetes mellitus (DM) tipe 2 merupakan suatu kelompok penyakit metabolik dengan karakteristik hiperglikemia yang terjadi karena resistensi insulin disertai defisiensi insulin relatif. Bervariasinya penggunaan terapi insulin tunggal atau kombinasi insulin dengan antidiabetik oral pada pasien DM tipe 2 dengan kontrol glukosa darah yang belum adekuat akan mengakibatkan adanya perbedaan dalam biaya dan efektivitas terapinya. Penelitian ini merupakan penelitian deskriptif yang dilakukan secara prospektif dan studi follow up dari bulan Mei sampai dengan Agustus 2017. Subyek penelitian adalah 70 pasien DM tipe 2 yang memenuhi kriteria inklusi. Data dianalisis untuk mengetahui jenis terapi dan biaya medis langsung. Efektivitas terapi dinilai dari tercapainya target $\mathrm{HbA} 1 \mathrm{c}<7 \%$ setelah follow up 3 bulan terapi dan tidak munculnya efek samping obat (hipoglikemia). Metode ACER digunakan untuk menganalisa jenis terapi insulin yang paling costeffective. Berdasarkan data yang didapatkan dari rekam medis RSUP Sanglah Denpasar, jumlah pasien DM tipe 2 lebih banyak diderita oleh laki-laki yaitu 47 orang dengan presentase $67,14 \%$, umur $>45$ tahun yaitu 63 orang dengan presentase $90,00 \%$. Jumlah pasien DM tipe 2 yang mencapai target GDP yaitu 34 orang dengan presentase $48,57 \%$, mencapai target $\mathrm{HbA1C}$ yaitu 60 orang dengan presentase $85 \%$. Jumlah pasien DM tipe 2 lebih banyak yang menggunakan terapi kombinasi insulin aspart dengan insulin glargine yaitu 42 orang dengan presentase $60 \%$. Total biaya medis langsung yang menunjukkan jumlah paling murah adalah penggunaan terapi insulin glargine dengan metformin yaitu Rp. 274.880,00. Efektivitas terapi yang lebih besar ditunjukkan oleh jenis terapi kombinasi insulin glargine dengan metformin yaitu 63,63\%. Efektivitas biaya yang lebih rendah ditunjukkan oleh jenis terapi kombinasi insulin glargine dengan metformin yaitu Rp. 4,32 persentase efektivitas.
\end{abstract}

Kata kunci: Analisis efektivitas biaya, Antidiabetik oral, DM tipe 2, Insulin.

\begin{abstract}
Diabetes mellitus (DM) type 2 is a group of metabolic diseases with characteristics of hyperglycemia that occurs because of insulin resistance with relative insulin deficiency. Variations in the use of single insulin therapy or a combination of insulin with oral antidiabetics in patients with type 2 DM with inadequate blood glucose control will result in differences in the cost and effectiveness of the therapy. This research is a descriptive study conducted prospectively and follow-up study from May to August 2017. The subjects were 70 patients with type $2 \mathrm{DM}$ who met the inclusion criteria. Data were analyzed to determine the type of therapy and direct medical costs. Therapeutic effectiveness was assessed from achievement of HbA1c target $<7 \%$ after 3 months follow-up therapy and no adverse drug effects (hypoglycemia). The ACER method is used to analyze the most cost-effective type of insulin therapy. Based on data obtained from the medical record Sanglah Hospital Denpasar, the number of patients with type 2 diabetes mellitus more than 47 people with a percentage of $67.14 \%$, age $>45$ years is 63 people with $90.00 \%$ percentage. The number of patients with type 2 diabetes mellitus that reaches the target of GDP is 34 people with a percentage of $48.57 \%$, reaching the target of $\mathrm{HbA} 1 \mathrm{C}$ is 60 people with $85 \%$ percentage. The number of patients with type 2 diabetes mellitus who use aspart insulin aspart therapy with insulin glargine is 42 people with a percentage of $60 \%$. The total direct medical cost that shows the cheapest amount is the use of insulin therapy glargine with metformin is Rp. $274.880,00$. Greater therapeutic effectiveness is indicated by a combination of insulin glargine with metformin, $63.63 \%$. Lower cost effectiveness is shown by the type of combination glargine insulin therapy with metformin which is Rp. 4.32 Percentage effectiveness.
\end{abstract}

Keywords: Cost effectiveness analysis, DM type 2, insulin, oral antidiabetics

• email korespondensi: udayani.wahyu@yahoo.com 


\section{PENDAHULUAN}

Diabetes mellitus (DM) adalah suatu penyakit gangguan metabolik yang diakibatkan oleh adanya gangguan sekresi insulin, kerja insulin ataupun keduanya (Dipiro et al., 2009). Diabetes mellitus (DM) tipe 2 umumnya terjadi karena kombinasi dari resistensi insulin dan berkurangnya sekresi insulin akibat menurunnya fungsi sel beta pankreas (Tjay dan Rahardja, 2007).

Prevalensi penyakit ini meningkat secara drastis di negara-negara industri dan negara berkembang, termasuk Indonesia. Badan Kesehatan Dunia (World Health Organization/WHO) memperkirakan jumlah penderita diabetes mellitus (DM) di Indonesia akan meningkat hingga dua sampai tiga kali lipat pada tahun 2030 dari 8,4 juta mencapai 21,3 juta orang (PERKENI, 2011).

Upaya terapi non farmakologi dan farmakologi telah dilakukan untuk meningkatkan kualitas hidup pasien diabetes mellitus. Terapi farmakologi untuk diabetes mellitus (DM) tipe 2 meliputi antidiabetik oral dan terapi insulin. Insulin diberikan untuk pasien yang memiliki nilai $\mathrm{HbA} 1 \mathrm{c} \geq 7,5 \%$ dengan kadar glukosa darah puasa $>250 \mathrm{mg} / \mathrm{dL}$, atau pasien yang gagal dengan terapi antidiabetik oral. Penggunaan insulin dapat dikombinasikan dengan antidiabetik oral apabila kadar glukosa darah tidak terkontrol dengan baik (HbA1c >7,5\%) dalam jangka waktu tiga bulan dengan dua antidiabetik oral (Spellman, 2007), sedangkan berdasarkan PERKENI pemberian insulin dapat diberikan pada pasien dengan kadar HbAlc lebih dari 9\% (PERKENI, 2011). American Diabetes Association (ADA) merekomendasikan penggunaan terapi insulin lebih awal pada pasien DM tipe 2 setelah gagalnya penatalaksanaan terapi melalui manajemen gaya hidup dan monoterapi dengan metformin tunggal (ADA, 2011).

Berdasarkan lama kerjanya,sediaan insulin dibedakan menjadi empat jenis, yaitu insulin kerja cepat, insulin kerja pendek, insulin kerja sedang, dan insulin kerja panjang. Untuk mencapai sasaran glukosa darah basal dipergunakan insulin kerja sedang atau panjang (insulin basal), sedangkan untuk kondisi glukosa darah basal (puasa) telah tercapai tetapi nilaiHbA1c belum mencapai target akan diberikan insulin kerja cepat atau insulin kerja pendek (insulin prandial) (PERKENI, 2011).

Terapi obat pada pasien diabetes mellitus dilakukan seumur hidup sehingga membutuhkan biaya yang sangat besar. Bervariasinya penggunaan terapi obat (terapi insulin tunggal atau kombinasi insulin dengan antidiabetik oral) akan mengakibatkan adanya perbedaan dalam biaya dan luaran terapinya. Jadi, untuk mengetahui efektivitas biaya penggunaan terapi insulin tunggal dan kombinasi insulin dengan antidiabetik oral diperlukan suatu analisis efektivitas biaya (metode yang menilai atau mencari cara yang paling murah dan efektif dalam mencapai target atau suatu tujuan yang sama dengan membandingkan hasil suatu kegiatan dengan biayanya) (Sanchez, 2008).

\section{METODE PENELITIAN}

Penelitian tentang analisis efektivitas biaya terapi insulin pada pasien diabetes mellitus tipe 2 rawat jalan di RSUP Sanglah merupakan jenis penelitian deskriptif yang dilakukan secara prospektif dan studi follow up (Lwanga dan S. Lemeshow, 1998). Adapun kriteria inklusi dalam penelitian ini sebagai berikut:

a. Pasien berumur diatas 35 tahun.

b. Pasien dengan DM tipe 2dengan kadar GDP $\geq 126 \mathrm{mg} / \mathrm{dL}$.

c. Pasien yang sedang melakukan kontrol ketika penelitian dilakukan.

d. Pasien yang bersedia menjadi responden.

e. Pasien yang mendapat terapi insulin tunggal atau terapi kombinasi insulin dengan antidiabetik oral.

\section{Demografi Subyek Penelitian \\ Demografi Subyek Penelitian Berdasarkan Jenis Kelamin. Persentase jumlah subjek berdasarkan jenis kelamin pada pasien DM tipe 2 rawat jalan di RSUP Sanglah Denpasar dapat dilihat pada tabel 1. Jumlah pasien DM tipe 2 lebih banyak diderita oleh laki-laki yaitu sejumlah 47 orang dengan presentase $67,14 \%$ dibandingkan dengan perempuan yaitu sejumlah 23 orang dengan presentase $32,86 \%$.}

Tabel 1. Karakteristik Pasien DM tipe 2 Berdasarkan Jenis Kelamin

\begin{tabular}{ccc}
\hline Jenis Kelamin & $\begin{array}{c}\text { Jumlah } \\
\text { (orang) }\end{array}$ & $\begin{array}{c}\text { Presentase } \\
(\boldsymbol{\%})\end{array}$ \\
\hline Laki-Laki & 47 & 67,14 \\
\hline Perempuan & 23 & 32,86 \\
\hline Total & $\mathbf{7 0}$ & $\mathbf{1 0 0 , 0 0}$ \\
\hline
\end{tabular}

\footnotetext{
Demografi Subyek Penelitian Berdasarkan Umur. Persentase jumlah subjek berdasarkan umur pada pasien DM tipe 2 rawat jalan di RSUP Sanglah Denpasardapat dilihat pada tabel 2. Jumlah pasien DM tipe 2 lebih banyak diderita oleh pasien dengan umur $>45$ tahun yaitu sejumlah 63 orang dengan presentase $90,00 \%$ dibandingkan
} 
dengan umur $\leq 45$ tahun yaitu sejumlah 7 orang dengan presentase $10,00 \%$.

Tabel 2. Karakteristik Pasien DM tipe 2

\begin{tabular}{ccc}
\multicolumn{3}{c}{ Berdasarkan Umur } \\
\hline $\begin{array}{c}\text { Kelompok } \\
\text { Umur }\end{array}$ & $\begin{array}{c}\text { Jumlah } \\
\text { (orang) }\end{array}$ & $\begin{array}{c}\text { Presentase } \\
(\mathbf{\%})\end{array}$ \\
\hline $\mathbf{4 5}$ tahun & 7 & 10,00 \\
\hline $\mathbf{4 5}$ tahun & 63 & 90,00 \\
\hline Total & $\mathbf{7 0}$ & $\mathbf{1 0 0}$ \\
\hline
\end{tabular}

Gambaran Tercapainya Target GDP pada Pasien DM tipe 2 Rawat Jalan RSUP Sanglah Denpasar. Persentase jumlah subjek berdasarkan tercapainya target GDP $(90-130 \mathrm{mg} / \mathrm{dL})$ pada pasien DM tipe 2 rawat jalan di RSUP Sanglah Denpasar dapat dilihat pada tabel 3. Jumlah pasien DM tipe 2 yang mencapai target GDP yaitu sejumlah 34 orang dengan presentase $48,57 \%$ sedangkan yang tidak mencapai target yaitu sejumlah 36 orang dengan presentase $51,43 \%$.

Tabel 3. Karakeristik Pasien DM tipe 2 Berdasarkan tercapainya GDP

\begin{tabular}{ccc}
\hline GDP $(\mathbf{9 0 - 1 3 0 m g / d L )}$ & $\begin{array}{c}\text { Jumlah } \\
\text { (orang) }\end{array}$ & $\begin{array}{c}\text { Presentase } \\
(\boldsymbol{\%})\end{array}$ \\
\hline Tercapai & 34 & 48,57 \\
\hline Tidak Tercapai & 36 & 51,43 \\
\hline Total & $\mathbf{7 0}$ & $\mathbf{1 0 0 , 0 0}$ \\
\hline
\end{tabular}

Gambaran Tercapainya Target HbA1C pada Pasien DM tipe 2 Rawat Jalan RSUP Sanglah Denpasar. Persentase jumlah subjek berdasarkan tercapainya target $\mathrm{HbA} 1 \mathrm{C}$, pada pasien DM tipe 2 rawat jalan di RSUP Sanglah Denpasar dapat dilihat pada tabel 4. Jumlah pasien DM tipe 2 yang mencapai target $\mathrm{HbA} 1 \mathrm{C}$ yaitu sejumlah 60 orang dengan presentase $85 \%$ sedangkan yang tidak mencapai target yaitu sejumlah 10 orang dengan presentase $15 \%$.

Tabel 4. Karakeristik Pasien DM tipe 2 Berdasarkan tercapainya $\mathrm{HbA1c}$

\begin{tabular}{ccc}
\hline HbA1C $(<\mathbf{9 \%})$ & $\begin{array}{c}\text { Jumlah } \\
\text { (orang) }\end{array}$ & $\begin{array}{c}\text { Presentase } \\
(\boldsymbol{\%})\end{array}$ \\
\hline Tercapai & 60 & 85 \\
\hline Tidak Tercapai & 10 & 15 \\
\hline Total & $\mathbf{7 0}$ & $\mathbf{1 0 0}$ \\
\hline
\end{tabular}

Penggunaan Jenis Terapi Insulin pada Pasien DM tipe 2 Rawat Jalan RSUP Sanglah Denpasar. Persentase jumlah subjek berdasarkan penggunaan jenis terapi insulin pada pasien DM tipe 2 rawat jalan di RSUP Sanglah Denpasar dapat dilihat pada tabel 5. Jumlah pasien DM tipe 2 lebih banyak yang menggunakan terapi kombinasi insulin aspart dengan insulin glargine yaitu sejumlah 42 orang dengan presentase $60 \%$, sedangkan yang menggunakan terapi kombinasi insulin glusiline dengan insulin glargine dan metformin lebih sedikit yaitu sejumlah 1 orang dengan presentase $1,43 \%$.

Tabel 5. Penggunaan Jenis Terapi Insulin pada Pasien DM tipe 2

\begin{tabular}{|c|c|c|c|c|}
\hline \multicolumn{2}{|c|}{ Golongan Obat } & Jenis Obat & $\begin{array}{l}\text { Jumlah } \\
\text { (orang) }\end{array}$ & $\begin{array}{c}\text { Presentase } \\
(\%)\end{array}$ \\
\hline \multicolumn{5}{|l|}{ Insulin Tunggal } \\
\hline Insulin kerja cepat & Insulin aspart & Novorapid®FlexPen® & 6 & 8,57 \\
\hline \multicolumn{5}{|l|}{ Kombinasi } \\
\hline \multirow{2}{*}{$\begin{array}{l}\text { Insulin kerja cepat + } \\
\text { insulin kerja } \\
\text { panjang }\end{array}$} & $\begin{array}{l}\text { Insulin aspart + Insulin } \\
\text { glargine }\end{array}$ & $\begin{array}{l}\text { Novorapid®FlexPen } \AA+ \\
\text { Lantus®FlexPen } \AA\end{array}$ & 43 & 61,43 \\
\hline & $\begin{array}{l}\text { Insulin glulisine }+ \text { Insulin } \\
\text { glargine }\end{array}$ & $\begin{array}{l}\text { Apidra }{ }^{\circledR} \text { FlexPen }{ }^{\circledR}+ \\
\text { Lantus }{ }^{\circledR} \text { FlexPen }{ }^{\circledR}\end{array}$ & 7 & 10,00 \\
\hline $\begin{array}{l}\text { Insulin kerja } \\
\text { panjang + Biguanid }\end{array}$ & Insulin glargine + Metformin & $\begin{array}{l}\text { Lantus } ® \text { FlexPen } ®+ \\
\text { Metformin }\end{array}$ & 11 & 15,71 \\
\hline \multirow{2}{*}{$\begin{array}{l}\text { Insulin kerja cepat + } \\
\text { insulin kerja } \\
\text { panjang + Biguanid }\end{array}$} & $\begin{array}{l}\text { Insulin aspart + Insulin } \\
\text { glargine + Metformin }\end{array}$ & $\begin{array}{l}\text { Novorapid®FlexPen } \AA+ \\
\text { Lantus®FlexPen } \AA+ \\
\text { Metformin }\end{array}$ & 2 & 2,86 \\
\hline & $\begin{array}{l}\text { Insulin glulisine + Insulin } \\
\text { glargine + Metformin }\end{array}$ & $\begin{array}{l}\text { Apidra }{ }^{\circledR} \text { FlexPen } ®+ \\
\text { Lantus }{ }^{\circledR} \text { FlexPen } ®+ \\
\text { Metformin }\end{array}$ & 1 & 1,43 \\
\hline
\end{tabular}


Analisis Efektivitas Biaya Medis Langsung pada Pasien DM tipe 2 Rawat Jalan RSUP Sanglah Denpasar. Persentase jumlah subjek berdasarkan efektivitas biaya medis langsung pada pasien DM tipe 2 rawat jalan di RSUP Sanglah
Denpasar dapat dilihat pada tabel berikut 6 . Total biaya medis langsung yang menunjukkan jumlah paling murah dibandingkan dengan yang lainnya adalah penggunaan terapi insulin glargine dengan metformin yaitu sebesar Rp. 274.880,00.

Tabel 6. Biaya Medis Langsung Penggunaan Insulin dan Kombinasi Insulin dengan OHO

\begin{tabular}{lcccccccc}
\hline \multicolumn{1}{c}{ Jenis Terapi } & $\mathbf{B 1}(\mathbf{R p})$ & $\mathbf{R 1}(\mathbf{R p})$ & $\mathbf{B 2}(\mathbf{R p})$ & $\mathbf{B 3}(\mathbf{R p})$ & $\mathbf{B 4}(\mathbf{R p})$ & $\begin{array}{c}\text { B2+B3+ } \\
\mathbf{B 4}(\mathbf{R p})\end{array}$ & $\mathbf{R 2}(\mathbf{R p})$ & $\mathbf{T}(\mathbf{R p})$ \\
\hline Insulin aspart & 986.571 & 328.857 & 92.000 & 60.000 & 60.000 & 212.000 & 53.000 & $\mathbf{3 8 1 . 8 5 7}$ \\
\hline $\begin{array}{l}\text { Insulin aspart + } \\
\text { Insulin glargin }\end{array}$ & 1.629 .171 & 543.057 & 92.000 & 60.000 & 60.000 & 212.000 & 53.000 & $\mathbf{5 9 6 . 0 5 7}$ \\
\hline $\begin{array}{l}\text { Insulin glulisine } \\
+ \text { Insulin } \\
\text { glargin }\end{array}$ & 1.629 .171 & 543.057 & 92.000 & 60.000 & 60.000 & 212.000 & 53.000 & $\mathbf{5 9 6 . 0 5 7}$ \\
\hline $\begin{array}{l}\text { Insulin glargin } \\
+ \text { Metformin }\end{array}$ & 665.640 & 221.880 & 92.000 & 60.000 & 60.000 & 212.000 & 53.000 & $\mathbf{2 7 4 . 8 8 0}$ \\
\hline $\begin{array}{l}\text { Insulin aspart + } \\
\text { Insulin glargin } \\
+ \text { Metformin }\end{array}$ & 1.652 .211 & 550.737 & 92.000 & 60.000 & 60.000 & 212.000 & 53.000 & $\mathbf{6 0 3 . 7 3 7}$ \\
\hline $\begin{array}{l}\text { Insulin glulisine } \\
+ \text { Insulin } \\
\text { glargin + } \\
\text { Metformin }\end{array}$ & 1.652 .211 & 550.737 & 92.000 & 60.000 & 60.000 & 212.000 & 53.000 & $\mathbf{6 0 3 . 7 3 7}$ \\
\hline
\end{tabular}

Keterangan:

B1= biaya obat

B3= biaya pemeriksaan dokter $\quad$ B4= biaya administrasi

B2= biaya laboratorium

$\mathrm{R} 1=$ rata-rata biaya obat $\quad \mathrm{R} 2=$ rata-rata penjumlahan $(\mathrm{B} 2+\mathrm{B} 3+\mathrm{B} 4)$

$\mathrm{T}=$ total biaya medis langsung tiap bulannya $(\mathrm{R} 1+\mathrm{R} 2)$

Tabel 7. Efektivitas Terapi Penggunaan Insulin dan Kombinasi Insulin dengan antidiabetik oral

\begin{tabular}{lcc}
\hline \multicolumn{1}{c}{ Jenis Terapi } & \multicolumn{2}{c}{ Efektivitas Terapi } \\
\cline { 2 - 3 } & $\begin{array}{c}\text { Jumlah } \\
(\text { orang) }\end{array}$ & $\begin{array}{c}\text { Presentase } \\
(\%)\end{array}$ \\
\hline Insulin aspart & 2 & 28,57 \\
\hline $\begin{array}{l}\text { Insulin aspart + Insulin } \\
\text { glargin }\end{array}$ & 20 & 47,62 \\
\hline $\begin{array}{l}\text { Insulin glulisine + Insulin } \\
\text { glargin }\end{array}$ & 4 & 57,14 \\
\hline $\begin{array}{l}\text { Insulin glargin+ } \\
\text { Metformin }\end{array}$ & 7 & 63,63 \\
\hline $\begin{array}{l}\text { Insulin aspart + Insulin } \\
\text { glargin + Metformin }\end{array}$ & 1 & 50 \\
\hline
\end{tabular}

Gambaran Efektivitas Terapi Penggunaan Insulin dan Kombinasi Insulin dengan OHO pada Pasien DM tipe 2 Rawat Jalan RSUP Sanglah Denpasar. Persentase jumlah subjek berdasarkan efektivitas terapi penggunaan insulin dan kombinasi insulin dengan $\mathrm{OHO}$ pada pasien DM tipe 2 rawat jalan di RSUP Sanglah Denpasar dapat dilihat pada tabel 7. Efektivitas terapi yang lebih besar ditunjukkan oleh jenis terapi kombinasi insulin glargine dengan metformin yaitu sebesar 63,63\%, sedangkan efektivitas terapi yang lebih kecil ditunjukkan oleh jenis terapi insulin aspart yaitu sebesar $28,57 \%$.

Efektivitas Biaya Penggunaan Insulin dan Kombinasi Insulin dengan OHO pada Pasien DM tipe 2 Rawat Jalan RSUP Sanglah Denpasar Berdasarkan Metode ACER. Persentase jumlah subjek berdasarkan efektivitas biaya penggunaan insulin dan kombinasi insulin dengan OHO pada pasien DM tipe 2 rawat jalan di RSUP Sanglah Denpasar dengan metode ACER dapat dilihat pada tabel 8. Efektivitas biaya yang lebih rendah ditunjukkan oleh jenis terapi kombinasi insulin glargine dengan metformin yaitu sebesar Rp. 4,32 persentase efektivitas, sedangkan efektivitas biaya yang lebih besar ditunjukkan oleh jenis terapi insulin aspart yaitu sebesar Rp. 13,36 persentase efektivitas. 
Tabel 8. Hasil Perhitungan ACER berdasarkan Total Biaya Medis Langsung

\begin{tabular}{lccc}
\hline \multicolumn{1}{c}{ Jenis Terapi } & $\begin{array}{c}\text { Total Biaya Medis } \\
\text { Langsung (Rp) }\end{array}$ & $\begin{array}{c}\text { Efektivitas } \\
\text { Terapi (\%) }\end{array}$ & $\begin{array}{c}\text { ACER } \\
\text { (Rp/\% efektivitas) }\end{array}$ \\
\hline Insulin aspart & 381.857 & 28,57 & 13,36 \\
\hline Insulin aspart + Insulin glargin & 596.057 & 47,62 & 12,52 \\
\hline Insulin glulisine + Insulin glargin & 596.057 & 57,14 & 10,43 \\
\hline Insulin glargin+ Metformin & 274.880 & 63,63 & 4,32 \\
\hline Insulin aspart + Insulin glargin + Metformin & 603.737 & 50 & 12,07 \\
\hline
\end{tabular}

\section{PEMBAHASAN}

Berdasarkan data yang didapatkan dari rekam medis RSUP Sanglah Denpasar didapatkan sampel pasien diabetes sebanyak 70 pasien yang memenuhi kriteria inklusi. Berdasarkan karakteristik pasien DM tipe 2 dilihat dari jenis kelamin, menunjukkan bahwa DM tipe 2 lebih banyak terjadi pada laki-laki yaitu sebesar $67,14 \%$ dengan jumlah 47 orang. Pada laki-laki mempunyai tingkat stres lebih besar dibandingkan dengan perempuan. Stres yang akut cenderung meningkatkan kadar glukosa darah. Stres emosional dapat mempengaruhi gula darah dalam beberapa cara. Manifestasi stres yang paling sering adalah diakibatkan oleh kenaikan dalam hormon stres yang bersikulasi dalam darah. Hormon stres seperti epineprin atau adrenalin dan kortisol, melepaskan glukosa yang disimpan dalam darah, akibatnya adalah kenaikan kadar gula darah yang sering menyebabkan peningkatan insulin (B. Michael, 2012).

Berdasarkan usia, hasil penelitian menunjukkan bahwa pasien DM tipe 2 lebih banyak terjadi pada usia di atas 45 tahun. Semakin bertambahnya usia maka akan terjadi penurunan aktifitas fisik. Berbagai perubahan terkait usia lainnya juga dapat menyebabkan perkembangan diabetes pada orang tua. Ini termasuk penuaan pada sel beta pankreas, dimana pada sel beta pankreas menghasilkan hormon insulin yang berperan penting dalam metabolisme karbohidrat dan juga lemak. Hipersekresi atau produksi berlebih hormon insulin menyebabkan hipoglikemia atau shok insulin. Hiposekresi atau produksi berkurang hormon insulin mengakibatkan hiperglikemia atau Diabetes Mellitus (Nala, 1996). Menurut penelitian semakin tua usia seseorang, insulin yang dikeluarkan juga semakin berkurang dan kemampuan tubuh mempertahankan diri juga semakin berkurang sehingga daya tahan tubuh menurun. Hal ini mempermudah masuknya virus dan dapat merusak pankreas sebagai penghasil insulin (Widharto, 2007). Dalam buku Usada Kencing Manis, menyebutkan bahwa penyakit DM tipe 2 ini juga disebabkan oleh pola dan gaya hidup yang salah, penyakit infeksi, disamping faktor keturunan dan sebab lainnya.

Efektivitas adalah keberhasilan antidiabetik untuk mencapai kadar gula darah menuju target. Target gula darah adalah GDP 90$130 \mathrm{mg} / \mathrm{dL}$ (Direktorat Bina Farmasi Komunitas dan Klinik, 2005). Dalam penelitian ini, nilai GDP digunakan sebagai parameter dalam target penatalaksanaan DM. Pada tabel 3 menunjukkan dari 70 orang pasien DM tipe 2, hanya 34 orang atau $48,57 \%$ yang mencapai target (GDP 90-130 $\mathrm{mg} / \mathrm{dL}$ ). Hal ini menunjukkan bahwa masih banyak pasien yang memiliki kadar GDP lebih tinggi dari parameter yang telah ditetapkan. Tingginya kadar gula yang dapat memicu terjadinya Diabetes Mellitus disebabkan oleh faktor-faktor gaya hidup dan lingkungan (peningkatan berat badan dan tidak melakukan olahraga secara cukup) (B. Michael, 2012).

Dalam membantu menurunkan kadar gula darah, salah satu cara yang dapat digunakan adalah memberikan terapi farmakologi pada pasien DM tipe 2. Pemberian terapi farmakologi untuk pasien DM tipe 2 dapat diberikan insulin maupun kombinasi antara insulin dengan antidiabetik oral. Pada tabel 5 menunjukkan bahwa penggunaan kombinasi insulin kerja cepat (insulin aspart) dengan insulin kerja panjang (insulin glargine) lebih banyak digunakan. Terapi insulin yang diberikan diupayakan mampu meniru pola sekresi insulin yang fisiologis (PERKENI, 2011).

Pada tabel 5. juga terlihat bahwa penggunaan kombinasi antara insulin kerja panjang (insulin glargine) dengan metformin juga banyak digunakan sebagai terapi, yaitu sejumlah 11 orang. Telah diketahui bahwa metformin mempunyai efek utama mengurangi produksi glukosa di hati (PERKENI, 2011). Kelebihan glukosa yang dihasilkan oleh hati merupakan sumber utama glukosa darah yang tinggi pada Diabetes Mellitustipe 2. Dengan kemampuan dalam mengurangi produksi glukosa di hati, maka metformin digunakan sebagai obat pilihan untuk 
Diabetes Mellitus tipe 2 (Champe, 2013). Insulin glargine merupakan insulin analog kerja panjang yang diindikasikan untuk memperbaiki kadar glukosa darah puasa pada penderita DM tipe 2. Insulin glargine memberikan fleksibilitas dalam penyesuaian dosis sesuai dengan kebutuhan penderita. Dari beberapa studi "treat to treat" dengan insulin glargine ditemukan bahwa hanya pemberian insulin basal ini sering ditemukan kendali glikemik yang baik, dan insulin basal sering diberikan bersamaan dengan metformin (BEU, 2016). Dari hasil penelitian ini menunjukkan bahwa penggunaan kombinasi metformin dengan insulin kerja panjang (insulin glargine), dapat menurunkan kadar GDP sehingga mencapai target. Kombinasi OHO dan insulin basal (insulin kerja panjang) pada umumnya dapat diperoleh kendali glukosa darah yang baik (PERKENI, 2011).

Biaya medis langsung adalah biaya yang paling sering diukur, merupakan input yang digunakan secara langsung untuk memberikan terapi (Andayani, 2013). Biaya medis langsung penggunaan insulin dan insulin kombinasi $\mathrm{OHO}$ pada pasien DM tipe 2 di rawat jalan RSUP Sanglah ini meliputi biaya obat, biaya pemeriksaan dokter, biaya laboratorium, dan biaya administrasi. Pada tabel 6 menunjukkan bahwa biaya penggunaan kombinasi insulin kerja panjang (insulin glargine) dengan metformin menghabiskan biaya yang lebih rendah dibandingkan dengan yang lainnya yaitu sebesar Rp 274.880,00. Dalam tabel 6 dapat dilihat bahwa biaya laboratorium (B2), biaya pemeriksaan dokter (B3) dan biaya administrasi (B4) tiap pasien sama, hanya saja biaya obat (B1) yang dikeluarkan tiap pasien berbeda. Dengan demikian, besar kecilnya total biaya medis langsung yang dikeluarkan oleh pasien ditentukan oleh besarnya biaya obat. Semakin besar biaya obat maka semakin tinggi pula biaya total medis langsungnya.

Efektivitas terapi pada penelitian ini dilihat daripencapaian target terapi GDP 90-130 $\mathrm{mg} / \mathrm{dL}$.Penilaian GDP dilakukan dengan tes GDP (Gula Darah Puasa) di laboratorium. Berdasarkan tabel 7 menunjukkan bahwa penggunan kombinasi insulin kerja panjang (insulin glargine) dengan metformin mempunyai efektivitas terapi yang paling tinggi yaitu 63,63\%. Dianjurkan pemberian insulin sebelum tidur sebagai tambahan terapi antidiabetes oral untuk pasien DM tipe 2 yang gagal mendapatkan efek maksimal pada terapi oral. Terapi yang digunakan adalah kombinasi insulin $\mathrm{NPH}$ (insulin glargine) sebelum tidur yang dikombinasikan dengan terapi Biguanide (metformin) (Katzung, 2002).
Efektivitas biaya merupakan analisis efektivitas biaya dilihat dari sudut pandang rumah sakit, dimana efektivitas yang diukur adalah gula darah pasien yang mencapai target. Perhitungan analisis ini menggunakan perhitungan ACER, dimana ACER diperoleh dari total biaya medis langsung dibagi dengan efektivitas terapi obat tersebut. Semakin rendah nilai ACER maka semakin tinggi nilai cost effective suatu kelompok (Alisa, 2015). Pada tabel 8 terlihat bahwa pola pengobatan yang paling cost effective adalah terapi kombinasi insulin glargine dengan metformin dengan nilai ACER terkecil sebesar Rp 4,32 persentase efektivitas terapi.

\section{KESIMPULAN}

1. Jenis insulin tunggal yang digunakan pada pasien DM tipe 2 rawat jalan di RSUP Sanglah Denpasar adalah insulin aspart. Sedangkan jenis terapi kombinasi insulin dengan antidiabetik oral yang digunakan pasien DM tipe 2 di rawat jalan RSUP Sanglah Denpasar adalah kombinasi insulin glargine dan metformin.

2. Total biaya medis langsung tiap bulan untuk insulin tunggal aspart adalah Rp 381.857,00. Sedangkan total biaya medis langsung tiap bulan untuk kombinasi insulin dengan antidiabetic oral yaitu insulin glargine dan metformin sebesar Rp 274.880,00.

3. Terapi insulin yang paling cost-effective berdasarkan ACER yaitu kombinasi insulin glargine dan metformin.

\section{DAFTAR PUSTAKA}

ADA. 2011. Standards of Medical Care in Diabetes-2011. Diabetes Care, Vol. 34 (1): 511-561.

Alisa. 2015. Analisis Efektivitas Biaya Antidiabetik Oral Pada Penderita Diabetes Melitus Tipe 2 Rawat Jalan Peserta BPJS Di Rumah Sakit Umum Daerah Dr. Moewardi Tahun 2014. Diakses pada 26 Agustus 2016. <eprints.ums.ac.id>

Andayani, Tri Murti. 2013. Farmakoekonomi: Prinsip dan Metodologi. Cetakan I. Yogyakarta: Bursa Ilmu Karangkajen. 
B. Michael. 2012. 100 Tanya-Jawab Mengenai Diabetes. Cetakan I. Jakarta: Indeks.

BEU XIII. 2016. Bali Endocrinologi Update: Endocrinology and Beyond. Denpasar: Percetakan Bali.

Champe, Pamela C. 2013. Farmakologi Ulasan Bergambar. Edisi 4. Jakarta: EGC.

Departemen Kesehatan Republik Indonesia. 2009. Profil Kesehatan Indonesia 2008. Jakarta : Departemen Kesehatan Republik Indonesia, hal. 72-78.

Dipiro, J. T., Dipiro, C. V.,Schwinghammer, T. L. dan Wells, B. G. 2009. Pharmacotherapy Handbook $7^{\text {th }}$ Edition. United State: The McGraw-Hill Companies, hal. 210-226.

Direktorat Bina Farmasi Komunitas dan Klinik. 2005. Pharmaceutical Care untuk Penyakit Diabetes Mellitus. Jakarta: Pustaka Utama, hal. 23-45.

Katzung, Bertram G. 2002. Farmakologi: Dasar dan Klinik. Edisi Pertama. Jakarta: Salemba Medika.
Lwanga, S. K. dan Lemeshow, L. 1998. Sample Size Determination in Health Studi. Geneva: WHO, hal. 206-209.

Nala, IGN. 1996. Usada Kencing Manis. Denpasar: Upada Sastra.

PERKENI. 2011. Konsesus Pengelolaan dan Pencegahan Diabetes Mellitus Tipe 2 di Indonesia 2011. Jakarta: Perkumpulan Endokrinologi Indonesia, hal. 1-30.

Sanchez, L. A. 2008. Pharmacoeconomic: Principal, Methods, and Application dalam Pharmacotherapy: A Pathophysiologic Approach, editor: L. Michael Posey. United State of America: McGraw-Hill Companies Inc.

Tjay, T.H. dan Rahardja, K. 2007. Obat-Obat Penting, Khasiat, Penggunaan, dan Efek-Efek Sampingnya. Jakarta: PT. Elex Media Komputindo.

Widharto. 2007. Kencing Manis (Diabetes). Jakarta Selatan: Sunda Kelapa Pustaka. 